\title{
“O BRASIL AINDA É UM IMENSO HOSPITAL" 1: Movimentos Higienistas e Antivacina no Brasil - da incipiente República à contemporaneidade
}

\author{
"BRAZIL IS STILL AN HUGE HOSPITAL": \\ Hygienist and Anti-vaccine Movements in Brazil - from the incipient Republic to the \\ contemporary
}

\author{
Maiquel Ângelo Dezordi Wermuth ${ }^{2}$ \\ Joice Graciele Nielsson ${ }^{3}$ \\ Gisele Cristina Tertuliano ${ }^{4}$
}

\section{RESUMO}

$\mathrm{O}$ artigo tematiza os movimentos antivacina em dois tempos da história brasileira: o início do século XX - a partir do episódio conhecido como Revolta da Vacina - e o início do século XXI, quando o país assiste à retomada dos discursos antivacina em face do cenário descortinado pela pandemia da Covid-19. A pergunta que orienta a pesquisa pode ser assim sintetizada: em que medida a desinformação e a condução autoritária de políticas públicas pode gerar, na população mais vulnerável, medos e receios diante das descobertas científicas voltadas à imunização em face de doenças? O texto divide-se em duas seções que correspondem, respectivamente, aos seus objetivos específicos: a primeira seção aborda o movimento antivacina ocorrido nos anos 1900, quando o país vivenciava a transição Império-República; a segunda parte do texto investiga os discursos antivacina no início deste século XXI, comparando-os àqueles adotados à época da incipiente República para averiguar em que medida se repristinam os mesmos temores sociais, diante de um cenário de profunda instabilidade e polarização política como o desencadeado pela pandemia da Covid-19. O método de abordagem empregado é o método fenomenológico.

Palavras-chave: Movimentos Antivacina. Programas de Imunização. Saúde Pública. Higienismo.

\footnotetext{
${ }^{1}$ O título deste texto faz alusão ao discurso proferido pelo médico e professor Miguel Pereira, por ocasião do regresso do Prof. Aloysio de Castro da República Argentina, em Outubro de 1916, e encontra-se disponível, na íntegra, em: http://www.periodicos.usp.br/revistadc/article/download/56845/59823. Acesso em: 12 jan. 2021.

2 Doutor e Mestre em Direito pela Universidade do Vale do Rio dos Sinos (UNISINOS). Especialista em Direito Penal e Direito Processual Penal e Bacharel em Direito pela Universidade Regional do Noroeste do Estado do Rio Grande do Sul (UNIJUÍ). Coordenador do Programa de Pós-Graduação Stricto Sensu em Direito - Mestrado e Doutorado em Direitos Humanos - da UNIJUII. Professor do Curso de Graduação em Direito da UNIJUÍ. Pesquisador Gaúcho da Fundação de Amparo à Pesquisa do Estado do Rio Grande do Sul (FAPERGS). Líder do Grupo de Pesquisa Biopolítica e Direitos Humanos, certificado pelo Conselho Nacional de Desenvolvimento Científico e Tecnológico (CNPq). Membro da Rede Brasileira de Pesquisa Jurídica em Direitos Humanos. Coordenador do Projeto PROCAD/CAPES "Rede de cooperação acadêmica e pesquisa: eficiência, efetividade e economicidade nas políticas de segurança pública com utilização de serviços de monitoração eletrônica e integração de bancos de dados".

${ }^{3}$ Professora-pesquisadora do Programa de Pós-Graduação - Mestrado e Doutorado em Direitos Humanos -, do Curso de Graduação em Direito na UNIJUI. Doutora em Direito (UNISINOS). Integrante do Grupo de Pesquisa Biopolítica e Direitos Humanos (CNPq).

${ }^{4}$ Graduada em Enfermagem pela Universidade Luterana do Brasil (1997); Graduada em Ciências Sociais pela Universidade Luterana do Brasil (2010); Mestra em Saúde Coletiva pela Universidade Luterana do Brasil (2006); Doutoranda em Saúde Coletiva pela Universidade do Vale do Rio dos Sinos (UNISINOS); Coordenadora do Serviço de Vigilância Epidemiológica Secretaria Municipal de Cachoeirinha-RS.
} 


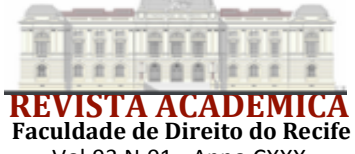

voldade de Direito do Recife

Vol.93 N.01 - Anno CXXX

\section{ABSTRACT}

The article focuses on anti-vaccine movements in two stages of Brazilian history: the beginning of the 20th century - from the episode known as the Vaccine Revolt - and the beginning of the 21 st century, when the country witnessed the resumption of anti-vaccine discourses in the face of scenario revealed by the Covid-19 pandemic. The question that guides the research can be summarized as follows: to what extent can the disinformation and authoritarian conduct of public policies generate, in the most vulnerable population, fears and fears in the face of scientific discoveries aimed at immunization in the face of diseases? The text is divided into two sections that correspond, respectively, to its specific objectives: the first section addresses the anti-vaccine movement that occurred in the $1900 \mathrm{~s}$, when the country was experiencing the Empire-Republic transition; the second part of the text investigates anti-vaccine speeches at the beginning of this 21 st century, comparing them to those adopted at the time of the incipient Republic in order to find out to what extent the same social fears are repristinating, in the face of a scenario of profound instability and political polarization such as the one triggered by the Covid-19 pandemic. The method of approach employed is the phenomenological method.

Keywords: Anti-vaccine Movements. Immunization Programs. Public health. Hygienism.

\section{CONSIDERAÇÕES INICIAIS}

A imunização deve ser entendida como uma medida de proteção específica do processo saúde-doença e é uma das formas mais seguras e eficazes de prevenir enfermidades e de reduzir a propagação das doenças existentes. Diante disso, o presente artigo tematiza os movimentos antivacina em dois tempos da história brasileira: o início do século $\mathrm{XX}$ - a partir do episódio conhecido como Revolta da Vacina - e o início do século XXI, quando o país assiste à retomada dos discursos antivacina - ainda mais acentuados no cenário descortinado pela pandemia da Covid-19.

Busca-se responder à seguinte pergunta de pesquisa: em que medida a desinformação e a condução autoritária de políticas públicas pode gerar, na população mais vulnerável, medos e receios diante das descobertas científicas voltadas à imunização em face de doenças?

Para responder à indagação, o texto encontra-se dividido em duas seções que correspondem, respectivamente, aos seus objetivos específicos. Inicialmente, aborda-se o movimento antivacina ocorrido nos anos 1900, quando o país vivenciava a transição ImpérioRepública, momento no qual as tensões políticas e as reformas urbanas com vistas à transformação do cenário da então capital republicana, a cidade do Rio de Janeiro, desencadearam, em face do terror gerado na população a partir de uma campanha de vacinação mal conduzida, a insurreição popular conhecida como Revolta da Vacina. A segunda parte do texto investiga os discursos antivacina no início deste século XXI, comparando-os àqueles adotados à época da incipiente República para averiguar em que medida se repristinam os mesmos temores - também em um cenário de profunda instabilidade e polarização política como o desencadeado pela pandemia da Covid-19.

$\mathrm{O}$ estudo parte de uma concepção de história caracterizada por períodos de avanços e retrocessos (pendular), e não por uma ideia de tempo histórico evolutivo e progressista (linear) (BENJAMIN, 2012; LE GOFF, 1996; TURINI, 2004), e emprega, como método de abordagem, o método fenomenológico (STEIN, 1979), uma vez que o presente estudo não parte da ideia de que exista uma cisão/afastamento entre os sujeitos pesquisadores (autores do artigo) e o objeto investigado, mas sim do pressuposto de que os primeiros estão diretamente implicados no 
segundo, ou seja, os autores do texto interagem com o objeto da pesquisa e sofrem as consequências dos seus resultados, o que estabelece um horizonte compreensivo que se mostra suficientemente fértil e adequado para a discussão da temática objeto desta investigação.

\section{NOS ALBORES DO SÉCULO XX... OS HOMENS DE CIÊNCIA E A REVOLTA DA VACINA}

Na virada do século XIX para o século XX, o cenário urbano do Rio de Janeiro vai paulatinamente se transformando. A substituição do trabalho escravo pelo assalariado, a decadência da cafeicultura no Estado, o desenvolvimento da indústria e do setor terciário da economia, a queda do Império e a Proclamação da República (com a respectiva substituição das elites no poder) são fatores que fizeram com que se passasse de uma pequena cidade comercial com feições coloniais para uma cidade industrial, com características de uma moderna metrópole capitalista, marcada por um aumento considerável da sua população, que atingia, em 1890 - um ano após a proclamação da República -, a marca de 522 mil pessoas (VAZ, 1994; CARVALHO, 1987). No entanto, a capital carioca evidenciava o quanto era difícil "a convivência entre o projeto republicano - que, recém inaugurado em novembro de 1889 , vendia uma imagem de modernidade - e a lembrança recente do sistema escravocrata", dificuldade esta que conduzia "à conformação de uma sociedade patriarcal, marcada pelas relações de ordem pessoal, violenta e na qual vigorava um profundo preconceito em relação ao trabalho braçal." (COSTA; SCHWARCZ, 2000, p. 11-12).

Para dar conta da nova realidade, a cidade do Rio de Janeiro precisou investir em modernos serviços públicos. Foram implementados sistemas de transporte coletivos (estradas de ferro e bondes de tração animal), redes de esgoto e de abastecimento de água, sistemas de comunicação (telégrafo), iluminação pública, etc. Como destacam Costa e Schwarcz (2000, p. 27), "a República representava a modernidade que se instalava no país, tirando-o da 'letargia da monarquia' ou da 'barbárie da escravidão'." Nesse momento, uma verdadeira "batalha simbólica" é travada: "nomes, hinos, bandeiras, heróis e modelos são substituídos (ou alterados os seus significados), com o intuito de marcar a diferença." (COSTA; SCHWARCZ, 2000, p. 27).

O então presidente Rodrigues Alves concedeu poderes ilimitados à equipe que seria responsável por fazer do Rio de Janeiro "uma vitrine para a captação dos interesses estrangeiros", a qual possuía três frentes bem distintas: a) modernização do porto, a cargo do engenheiro Lauro Müller; b) saneamento da cidade, a cargo do médico sanitarista Oswaldo Cruz; e c) reforma urbana, a ser conduzida pelo engenheiro Pereira Passos (COSTA; SCHWARCZ, 2000, p. 29).

Esse processo de modernização - principalmente dos sistemas de abastecimento de água e escoamento de esgoto e de transporte - esteve diretamente relacionado à exclusão de alguns contingentes populacionais do cenário urbano, principalmente dos ex-escravos que até então eram responsáveis pelo trabalho braçal relacionado ao fornecimento de água, eliminação de dejetos e deslocamento de cargas. O trabalho escravo não foi apenas substituído pelo assalariado, mas também pelas inovações tecnológicas que exigiam menos trabalhadores e maior qualificação. Com isso, "os escravos foram dispensados junto com liteiras, carroças, baldes e barris", sendo colocados "à margem da economia urbana, excluídos pela modernização." (VAZ, 1994, p. 582). Nesse sentido, paralelamente à transformação da capital do Rio de Janeiro em uma vitrine para os interesses estrangeiros, ocorreu o paulatino processo de expulsão da população pobre que residia nos casarões da região central, estabelecendo-se, segundo Costa e Schwarcz (2000, p. 28), uma 'ditadura do 'bota-abaixo', que demolia residências e disseminava as favelas, cortiços e hotéis baratos - os 'zunga' -, onde famílias inteiras deitavam-se no chão", e isso sem 
mencionar a "repressão às festas populares e procissões que passavam, igualmente, por esse 'processo civilizatório': saía o entrudo, entrava o limpo Carnaval de Veneza."

Isso significa que, se até então os escravos e trabalhadores livres pobres eram "invisíveis" enquanto "fonte de perigo médico", é porque "o pobre funcionava no interior da cidade como uma condição da existência urbana" - na medida em que realizavam tarefas imprescindíveis à vida citadina como as acima descritas - integrando a sua paisagem. E, "na medida em que faziam parte da paisagem urbana, como os esgotos e a canalização, os pobres não podiam ser postos em questão, não podiam ser vistos como um perigo. No nível em que se colocavam, eles eram bastante úteis." (FOUCAULT, 2003, p. 94).

Ao lado de outros marginalizados, como os libertos e os trabalhadores migrantes nacionais e imigrantes estrangeiros, que afluíam à cidade em busca de meios de sobrevivência, essa população passou a agrupar-se em habitações coletivas insalubres - como as estalagens ${ }^{5}$ e as casas-de-cômodos ${ }^{6}$ - indistintamente chamadas de cortiços ${ }^{7}$. Nesse período, a construção de cortiços se transformou em uma prática comum entre os proprietários de imóveis, tanto que, "na virada do século estavam presentes por toda a cidade, abrigando considerável parcela da população." (VAZ, 1994, p. 583). De acordo com Carvalho (1987), em 1888 o Rio de Janeiro abrigava, em suas 1.331 estalagens e 18.866 quartos de aluguel, um contingente aproximado de 46.680 pessoas. Essa concentração populacional e as atividades desenvolvidas no espaço urbano eram, incompatíveis com as condições sanitárias existentes, razão pela qual, como destacam Costa e Schwarcz (2000, p. 117), "uma série de moléstias grassava no local, gerando verdadeiros surtos epidêmicos", como é o caso da febre amarela, "que aqui aportou em 1849, fazendo vítimas durante cinquenta anos, uma vez que não se tinha ideia dos agentes transmissores da doença."

Naturalmente, a urbanização eaumento da aglomeração de pessoas no espaço das cidades modifica o modo como a questão da pobreza passa a ser enfrentada. A crescente urbanização impõe a "necessidade de um poder político capaz de esquadrinhar esta população urbana." (FOUCAULT, 2003, p. 86). Nesse contexto é que surge a preocupação com a higiene pública, considerando-se que "a ação governamental era imprescindível a fim de que se empreendessem políticas públicas de saneamento.” (COSTA; SCHWARCZ, 2000, p. 117).

Com efeito, a multiplicação dos cortiços e habitações populares passa a ser vista como inversamente proporcional às condições de higiene desses locais, criando o ambiente ideal para a proliferação de doenças que se transformavam em epidemias que ameaçavam atingir toda a cidade. De acordo com Costa e Schwarcz (2000, p. 118), a incidência de moléstias contagiosas, nesta época, era aterradora: a tuberculose era responsável por $15 \%$ das mortes no Rio de Janeiro, seguida por outras doenças como febre amarela, varíola, malária, cólera, beribéri, febre tifoide, sarampo, coqueluche, peste, lepra, escarlatina - doenças que, juntas, representavam $42 \%$ do total de mortes registradas em 1895 na cidade, por ocasião da publicação de um dos primeiros quadros de demografia sanitária, publicado pela revista Brasil Médico. Somente no período de 1868 a 1914, morreram no Rio de Janeiro, vítimas da tuberculose, 11.666 pessoas.

A relação entre as habitações populares e as epidemias não tardou a acontecer. Em pouco tempo, os cortiços passaram a ser tratados como "fontes de perigo". De acordo com Vaz (1994, p. 584),

\footnotetext{
5 “As estalagens eram grupos de minúsculas casas térreas enfileiradas — os quartos ou casinhas —, de dimensões, compartimentos e demais elementos reduzidos ao extremo, que surgiram por volta de 1850." (VAZ, 1994, p. 583).

6 "As casas-de-alugar- -cômodos, ou casas-de-cômodos, eram casas subdivididas internamente que se multiplicaram no período republicano." (VAZ, 1994, p. 583).

"O uso do termo cortiço para habitação coletiva provém, provavelmente, da associação que se fazia entre as estalagens e as colmeias: formadas por minúsculos casulos que abrigavam as abelhas-operárias, que passavam o dia trabalhando em meio a intenso zumbido. Outra hipótese, mais remota, sobre a origem do termo se apoia na associação a uma pequena corte, isto é, a um pátio, como no caso alemão, que denomina de 'Hof' (corte ou pátio) o conjunto de pequenas casas ao redor de um pátio, e também no caso português, que denomina de 'pátio' (em Lisboa) e 'ilha' (no Porto) o que chamamos de cortiço.” (VAZ, 1994, p. 583).
} 


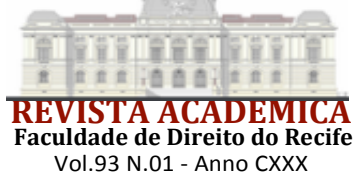

sucediam-se as denúncias de médicos higienistas, relatórios de engenheiros sanitaristas, pareceres de comissões de notáveis e editoriais da imprensa, apontando, por um lado, para as péssimas condições físicas das moradias (insalubridade, má distribuição dos espaços internos, falta de iluminação e ventilação, insuficiência e deficiência de instalações sanitárias) e consequente degradação da saúde da população moradora nessas condições e, por outro lado, para a superlotação, a promiscuidade e a depravação moral que as acompanhava.

Nasce, no Brasil, com um século de "atraso", a preocupação com aquilo que Foucault (2003) denomina - a partir do contexto francês das últimas décadas do século XVIII - "medicina urbana", preocupada em esquadrinhar lugares de acúmulo de tudo que pode provocar doenças no espaço urbano, controlando a circulação do ar e da água, de modo a fazer com que esses elementos se mantenham "sadios", a fim de evitar contaminações, organizando os diferentes elementos necessários à vida comum da cidade, como as fontes, esgotos, etc. Por meio dessas medidas, surge a noção de "salubridade" 8 , que tem uma importância considerável para a medicina social.

Marca-se, assim, no país, o surgimento da ideologia da higiene, no lastro da equiparação conceitual equivocada já estabelecida entre "classes pobres" e "classes perigosas", que aparece no debate parlamentar no Brasil Imperial nos meses subsequentes à abolição da escravidão, em 1888, decorrente da preocupação dos Deputados do Império em "garantir a organização do mundo do trabalho sem o recurso às políticas de domínio características do cativeiro." (CHALHOUB, 1996, p. 23). A pauta, naquele momento, era a repressão à ociosidade, a qual se apresentava como principal "vício" a ser combatido, na medida em que o "bom cidadão" passa a ser visto como aquele que tem gosto pelo trabalho, pela poupança e pelo conforto que isso pode proporcionar, ao passo que o indivíduo que não acumula, que vive na pobreza, torna-se imediatamente alvo de suspeição. "Os pobres carregam vícios, os vícios produzem os malfeitores, os malfeitores são perigosos à sociedade; juntando os extremos da cadeia, temos a noção de que os pobres são, por definição, perigosos." (CHALHOUB, 1996, p. 22). Esse movimento permitiu o estabelecimento de estratégias de controle e disciplinamento das classes subalternizadas, fora dos limites da propriedade dominada pelos antigos senhores escravocratas, o que implicava o recurso constante às agências do sistema punitivo (WERMUTH, 2011).

Evidencia-se, então, a partir de uma leitura foucaultiana (2003), o nascimento de um conjunto de práticas e saberes que, em essência, se apresentam como formas de controle da saúde e, reflexamente, do corpo das classes pauperizadas para torná-las/deixá-las aptas ao trabalho e, em razão disso, não apresentarem tantos perigos para as classes mais ricas. Por meio da análise do "nascimento da medicina social" em terras brasileiras, é possível compreender como determinados saberes e discursos (medicina, estatística, demografia, direito, etc) influenciaram políticas públicas de controle/regulação de problemas relativos à questão da população, ou seja, da intensificação do convívio humano no espaço urbano.

$\mathrm{O}$ caso do combate à febre amarela permite um exemplo privilegiado desses processos, na medida em que esta doença servia como "inspiração para o exercício de uma medicina e de uma ciência que se acreditavam redentoras e assim atestavam sua utilidade pública." Mesmo que a doença que mais matasse, à época, fosse a tuberculose, a prioridade da ação do governo brasileiro sobre a febre amarela pode ser explicada por dois motivos: primeiramente, a existência dessa doença "assustava os imigrantes europeus, tornando-se um obstáculo à política encontrada

${ }^{8}$ Como salienta Foucault (2003, p. 93), “salubridade não é a mesma coisa que saúde, e sim o estado das coisas, do meio e seus elementos constitutivos, que permitem a melhor saúde possível. Salubridade é a base material e social capaz de assegurar a melhor saúde possível dos indivíduos. E é correlativamente a ela que aparece a noção de higiene pública, técnica de controle e de modificação dos elementos materiais do meio que são suscetíveis de favorecer ou, ao contrário, prejudicar a saúde. Salubridade e insalubridade são o estado das coisas e do meioenquanto afetam a saúde; a higiene pública - no séc. XIX, a noção essencial da medicina social francesa - é o controle político-científico deste meio."

WERMUTH, Maiquel Ângelo Dezordi; NIELSSON, Joice Graciele; TERTULIANO, Gisele Cristina. "O BRASIL AINDA É UM IMENSO HOSPITAL": MOVIMENTOS HIGIENISTAS E ANTIVACINA NO BRASIL - DA INCIPIENTE REPÚBLICA À CONTEMPORANEIDADE. Revista Acadêmica da Faculdade de Direito do Recife - ISSN: 2448-2307, v. 93, n.1, p.350-370 Abr. 2021. ISSN 2448-2307. <Disponível em: https://periodicos.ufpe.br/revistas/ACADEMICA/article/view/249745> 
pelo governo para o problema da mão-de-obra"; em segundo lugar, "a tuberculose acometia um número maior de negros e mestiços - por sua própria condição de vida - e era a eles associada". Assim, de qualquer forma, "a ideologia do branqueamento da raça estava na base da escolha." (COSTA; SCHWARCZ, 2000, p. 118-119).

A partir desses saberes e discursos, técnicas de poder são criadas e colocadas em funcionamento para organização dos espaços, para higienização das cidades e para o estabelecimento de políticas sanitárias que objetivam o controle de determinados estratos sociais em nome da segurança do conjunto da população - evidenciando-se, de plano, um descompasso "entre uma ciência determinista e homogeneizada e uma população desinformada e pouco preparada para a invasão domiciliar que então se realizava." (COSTA; SCHWARCZ, 2000, p. 119).

Nesse movimento, a medicina cada vez mais passa a investir no corpo do indivíduo para além do âmbito estritamente privado de sua existência, avançando em direção ao domínio da coletividade - evidenciando a passagem de um modelo disciplinar (próprio dos espaços de produção alicerçados na mão-de-obra escrava que caracterizaram o período imperial) para um modelo biopolítico ${ }^{9}$ (gestão coletiva da população livre em um momento de ascensão do movimento de urbanização do país). Tratava-se da "introdução de uma medicina intervencionista que, em nome da higiene, alcançava espaços inusitados de atuação que iam do indivíduo à comunidade e, quiçá, priorizavam a própria nação.” (COSTA; SCHWARCZ, 2000, p. 122).

Esta gestão biopolítica da população, no entanto, "não pode ser ingenuamente compreendida pelo seu 'caráter humanitário' de administrar, por meio de intervenções políticas, as condições de vida da população".Mais do que isso, é importante salientar que "há um aspecto violento desse controle", que "reside justamente na exigência contínua e crescente da morte em massa do 'outro', enquanto instrumento privilegiado para a garantia de melhores meios de sobrevivência de uma determinada população." (SANTOS; WERMUTH, 2016, p. 418). É nesse sentido que se pode compreender, no Brasil da incipiente República, a adoção "de projetos de eugenia que visavam controlar a reprodução da população, privilegiando um tipo cada vez mais branqueado." (COSTA; SCHWARCZ, 2000, p. 122).

Neste estado de coisas, o racismo de Estado, nas palavras de Foucault (2010, p. 52-53), passa a ser exercido pela sociedade sobre ela mesma, ou seja, "sobre seus próprios elementos, sobre os seus próprios produtos". Trata-se, portanto, de um "racismo interno, o da purificação permanente, que será uma das dimensões fundamentais da normalização social". Segundo Ayub (2014, p. 109), "a purificação das raças alimenta os anseios de um poder que investe sobre a vida", fazendo com que se crie a necessidade de que a raça impura seja extirpada "no intuito de se evitar o desencadeamento de uma contaminação generalizada." De acordo com Bazzicalupo (2017, p. 50), "a normalização de emergência e de exceção multiplica o risco de morte para determinados grupos da população ou condena à morte política através da expulsão, da rejeição."

A partir desse marco, a ideologia da higiene, no Brasil da incipiente República, foi uma importante aliada no planejamento de estratégias de controle das camadas subalternizadas da população. Suas habitações coletivas passaram a ser consideradas focos de epidemias e terreno fértil para a proliferação de todos os tipos de vícios que poderiam "contaminar" a sociedade como um todo. O racismo de estado estava explícito: "a mestiçagem era considerada um grande mal; quase uma sina local" e se supunha que "as raças correspondiam a dados essenciais e fixos, e que a humanidade se dividia a partir delas em hierarquias naturais." Nesse estado de coisas, "cada raça teria potenciais distintos e inalteráveis, estando os brancos caucasianos no topo da pirâmide social e evolutiva, e os negros na base." No entanto, "piores que as raças puras seriam

\footnotetext{
${ }^{9}$ A biopolítica, nesse sentido, representa, a partir na ótica foucaultiana, o momento a partir do qual a própria vida, ou seja, a facticidade do viver, "é o critério e o fim em base aos quais se exercita o poder", o que implica "fazer da vida objeto de um juízo político de valor tanto para selecioná-la como para melhorá-la.” (BAZZICALUPO, 2017, p. 34).
} 


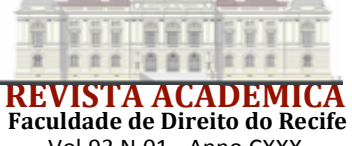

Veculdade de Direito do Recife

ol.93 N.01 - Anno CXXX

as mestiçadas, as quais [...] eram passíveis de todo tipo de 'degeneração hereditária'." (SCHWARCZ; STARLING, 2015, p. 329).

Foram, então, criados órgãos administrativos responsáveis pela questão da saúde pública, os quais passaram a estabelecer regulamentos que tinham por alvo principal impedir a proliferação dos cortiços, proibindo a construção de tais habitações em determinadas regiões da cidade $^{10}$. Em breve, essa preocupação voltou-se para a necessidade de destruição desses espaços. De acordo com Scliar (2002, p. 55), "o saneamento passou a ser visto não apenas como uma estratégia de saúde", mas como uma causa, um ideal, fazendo "ressurgir a dimensão social da teoria do miasma; de novo, as más condições de vida eram apontadas como causa de doenças."

Neste contexto de combate às habitações insalubres, dois agentes principais são destacados por Vaz (1994): por um lado, o Estado, que atuava restringindo a construção de novas habitações coletivas, impondo normas higiênicas e fechando e destruindo os cortiços existentes; de outro, os empresários do nascente setor imobiliário, que buscavam introduzir um novo padrão de edificação na cidade.

Sobre o tema, Coelho (2014, p. 176) assevera que a preocupação das autoridades, imprensa e setores "ilustrados" da sociedade com a higiene do povo - apesar de reportar às teses higienistas em voga na Europa - não era orientada apenas pelas "bizarrices de um darwinismo social". A elas devem ser associados os interesses econômicos que, "orientados por um liberalismo fisiológico", e "aliados ao interesse de um replanejamento urbano que tinha como modelo as metrópoles europeias", representaram "as forças determinantes para a reconfiguração do espaço público que se propunha levar a termo." (COELHO, 2014, p. 176). Nesse cenário, "os cortiços eram o pesadelo; a cidade burguesa, afrancesada, o sonho dos progressistas. A realidade era conflituosa." (PREFEITURA DA CIDADE DO RIO DE JANEIRO, 2002, p. 7).

A ciência dos higienistas legitimava as pretensões dos empresários, que insistiam na necessidade de uma "terapia radical no centro da cidade", enfatizando que tal terapia alicerçavase em dois pilares essenciais: "a destruição das moradias consideradas insalubres e a diminuição da aglomeração de pessoas naquela área." (CHALHOUB, 1996, p. 52).

Na leitura de Costa e Schwarcz (2000, p. 119), pela ótica dos "homens de ciência" da época, "da sociedade entendida como um grande hospital esperava-se a passividade mais absoluta", cabendo a eles, os especialistas, "planejar reformas urbanas, dividir a população entre doentes e sãos, ou administrar remédios em larga escala." Os projetos de saneamento, nesse sentido, escapavam "do terreno estrito da medicina" e propunham "medidas diretas de intervenção na realidade social.” (SCHWARCZ, 2017, p. 297). Essas medidas, que faziam do Brasil um "imenso hospital", foram muito bem apreendidas na charge publicada na edição $\mathrm{n}^{0} 247$ da Revista "O Malho", em 8 de julho de 1907, a seguir reproduzida:

\footnotetext{
10 "Várias posturas municipais restringiram progressivamente a presença das habitações coletivas no núcleo, ampliando a zona de proibição de cortiços. A proibição de construção de cortiços na área central provocou o desaparecimento de muitos, aprisionados num impasse. Os cortiços eram fechados e multados pelos serviços de higiene, que impunham a seus proprietários a obrigação de realizar melhoramentos de caráter sanitário para reabrir o estabelecimento. No entanto, eram proibidos de realizar estas obras pelo órgão municipal de licenciamento de construções." (VAZ, 1994, p. 585).
} 
Figura 1: "Uma limpeza indispensável"

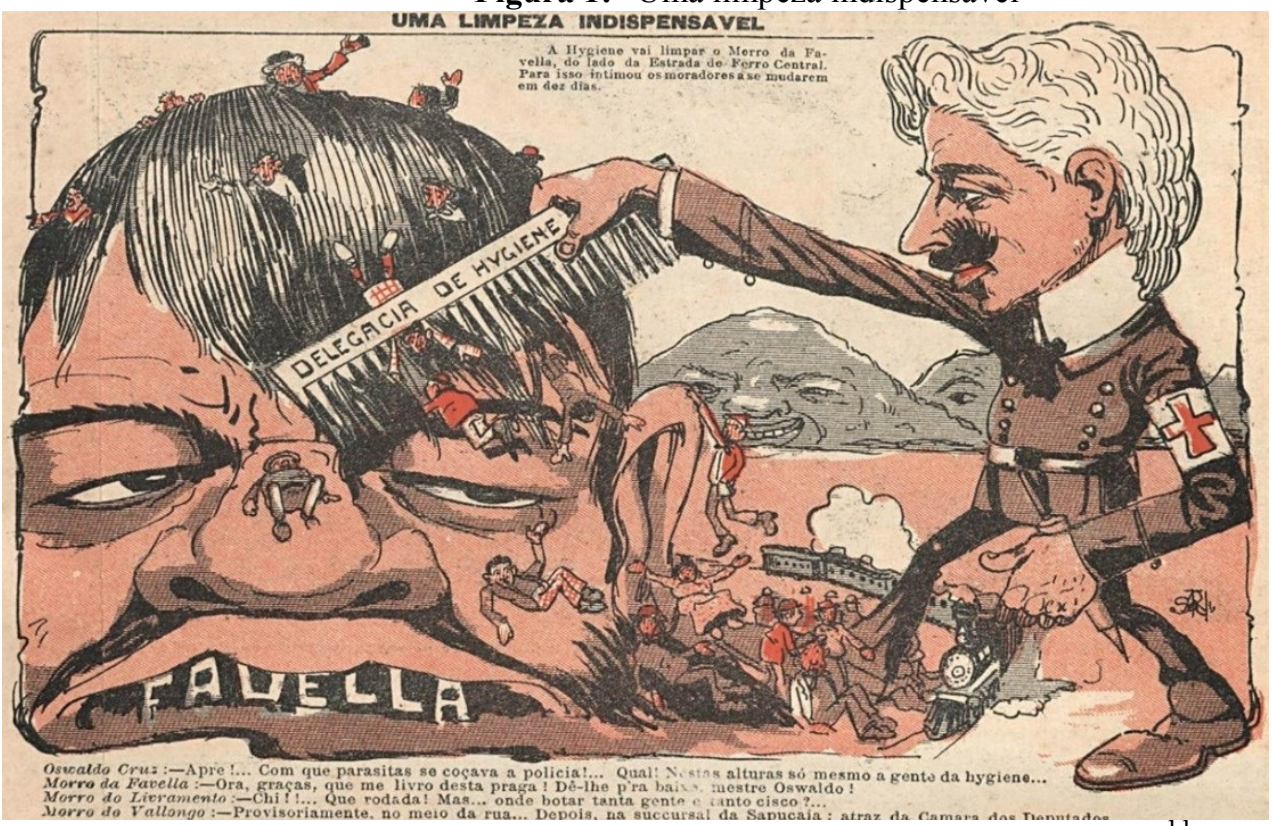

Fonte: Revista "O Malho", edição 247, de 8 de julho de $1907^{11}$.

E é justamente neste período que, paralelamente à destruição das habitações populares, começam a ocorrer as "grandes vacinações", agora ministradas "em nome do bem geral da nação, a despeito das tensões que essa prática acabava gerando", na medida em que, "impostas como se se medicasse um paciente em coma - sem estado de consciência ou arbítrio -, as campanhas transformavam-se em medidas cada vez mais impopulares." (COSTA; SCHWARCZ, 2000, p. 120). Como ressalta Sevcenko (2018, p. 70), "se alguém escapara dos furores demolitórios de Lauro Müller e do prefeito Pereira Passos, não teria mais como escapulir aos poderes inquisitoriais de Osvaldo Cruz."

A insurreição denominada Revolta da Vacina, ocorrida entre os dias 10 e 16 de novembro de em 1904, responde justamente a esta lógica e insere-se neste contexto, podendo ser considerada, de acordo com Sevcenko (2018, p. 14), uma das "mais pungentes demonstrações de resistência dos grupos subalternos do país contra a exploração, a discriminação e o tratamento espúrio a que eram submetidos pela administração pública nessa fase da nossa história."

A Lei $n^{0} 1.261$, de 31 de outubro daquele ano (BRASIL, 1904) e seu decreto regulamentador, que tornavam obrigatória a vacinação contra a varíola, foi recebida pela população como medida autoritária decorrente de uma "ditadura sanitária", capitaneada por Oswaldo $\mathrm{Cruz}^{12}$ (COSTA; SCHWARCZ, 2000; SEVCENKO, 2018).Os termos dessa legislação eram bastante rígidos, abarcavam desde os recém nascidos até os idosos, e impunha-lhes, além da vacinação, exames e reexames, ameaçando a população "com multas pesadas e demissões sumárias, limitando as oportunidades de recursos, defesas e omissões", objetivando, assim, realizar "uma campanha maciça, rápida, sem nenhum embaraço e fulminante", sem sequer

\footnotetext{
${ }^{11}$ Referida imagem pode ser acessada em: https://pt.wikipedia.org/wiki/Oswaldo_Cruz\#/media/Ficheiro:Oswaldo_Cruz_passa_o_pente_fino_da_\%E2\%80\% 9CDelegacia_da_Hygiene\%22_no_Morro_da_Favela.jpg. Acesso em: 13 jan. 2021.

12 “Convidado para assumir a coordenação dos esforços de desinfecção e profilaxia da capital, Osvaldo Cruz impõe igualmente condições severas ao presidente, conforme nos relata o repórter do Jornal do Comércio, presente ao encontro decisivo dos dois personagens. Exige o médico: 'Preciso de recursos e da mais completa independência de ação. O governo me dará tudo de que necessite, deixando-me livre na escolha de meus auxiliares, sem nenhuma interferência política.' Ato contínuo, Rodrigues Alves acata o requisito autoritário do cientista e o nomeia diretorgeral de Saúde Pública, com plenos poderes amparados pelo domínio federal.” (SEVCENKO, 2018, p. 68-69).
} 
cogitar a "preparação psicológica da população, da qual só se exigia a submissão incondicional." (SEVCENKO, 2018, p. 26).

O povo, nas ruas, quebrou meios de transporte, depredou edifícios e atacou agentes higienistas. De acordo com Sevcenko (2018, p. 28), "o combate era intenso, em nenhum lugar a polícia conseguia assumir o controle da situação", de modo que "o Exército é convocado para reforçar a guarda do palácio presidencial", o que também não se mostrou suficiente, razão pela qual foram convocadas unidades do exército de regiões limítrofes, de Minas Gerais e São Paulo, além de armar toda a corporação dos bombeiros contra os insurrectos. Ocorre que a resistência popular era tanta que o governo "precisou apelar para recursos ainda mais extremos: determinou o bombardeio de bairros e regiões costeiras por suas embarcações de guerra. Finalmente convocou a Guarda Nacional", com o que paulatinamente foi possível sufocar a insurreição. Como reação, o governo decretou estado de sítio, suspendendo, consequentemente, direitos constitucionais e prendendo os líderes do movimento, os quais foram deportados para o atual Estado do Acre. Como saldo, a revolta deixou 30 mortos e 110 feridos, segundo registros da época (SCHWARCZ; STARLING, 2015, p. 329), além de um rastro de destruição na cidade. No dia 16 de novembro, o governo revoga a obrigatoriedade da vacina antivariólica (SEVCENKO, 2018).

O modo violento com que se deu a repressão à Revolta da Vacina é indicativo, segundo Sevcenko (2018, p. 110), "de outros elementos discriminatórios e brutais, ligados à política de contenção e controle das camadas humildes", estratégia que, segundo o autor, "procede do modelo de tratamento reservado aos escravos que vigorou até a Abolição." O que se evidencia, portanto, é que "o que antes fora uma justiça particular, aplicada no interior das fazendas e casas senhoriais, tornou-se prática institucional da própria autoridade pública no regime republicano", de modo que, aos pobres, não se atribuía o status de cidadãos que é inerente ao regime republicano, mas sim um "tratamento similar ao aplicado aos antigos escravos, controlados pelo terror, ameaças, humilhações e espancamentos, com o Estado assumindo as funções de gerente e de feitor." Esse movimento indica que, na transição de uma sociedade senhorial para a sociedade burguesa, "muitos elementos da primeira foram preservados e assimilados pela segunda", a demonstrar que "a vasta experiência no controle das massas subalternas da sociedade imperial não podia ser desperdiçada pela nova elite."

Por outro lado, a Revolta da Vacina também permite compreender, na esteira de Costa e Schwarcz (2000, p. 122), os impasses próprios do final do século XIX e início do século XX, "com tantas utopias tão pouco partilhadas", uma vez que "na revolta diferentes 'Brasis' estavam em questão; muitos projetos em pauta." E, segundo as autoras, "nada revela melhor a marcha dos acontecimentos do que a própria maneira como Oswaldo Cruz foi representado nas caricaturas de época", tanto na apresentada na Figura 2, acima, quanto na charge publicada na edição 111 da Revista "O Malho", em 29 de outubro de 1904, a seguir reproduzida. 


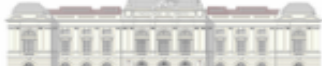

REVISTA ACADEIVICA

Faculdade de Direito do Recife

Vol.93 N.01 - Anno CXXX

Figura 2:"Guerra Vaccino-obrigateza!"

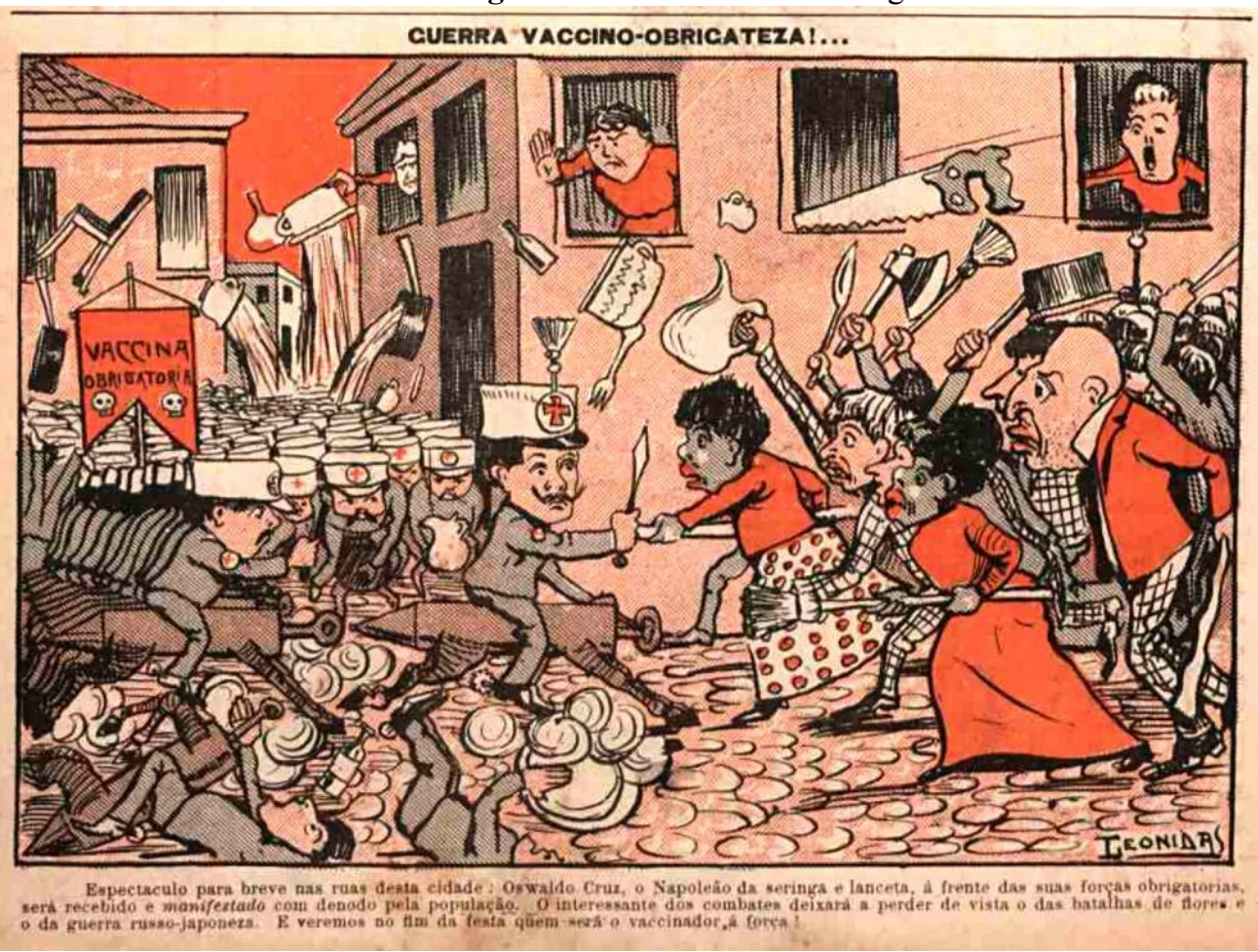

Fonte:Revista “O Malho”, edição 111, de 29 de outubro de $1904^{13}$.

O fato é que, se a partir de 1903 o médico sanitarista Oswaldo Cruz era apresentado como "um monstro ou um demônio, pouco a pouco foi se humanizando até, em 1907, se transformar num misto de anjo e deus". Isso foi "o resultado de um processo acelerado de mudanças, que fazia de um modelo de civilização uma via quase obrigatória." A partir da "medalha de ouro que recebeu a representação brasileira no XIV Congresso Internacional de Higiene, reunido em Berlim em 1907, Oswaldo Cruz enchia-se de glórias e, com ele, mais uma vez o país era reconhecido entre a comunidade científica internacional." (COSTA; SCHWARCZ, 2000, p. 122).

Passo mais de um século desse episódio, o país depara-se, nos albores do século XXI, com a pandemia ocasionada pelo novo coronavírus (Covid-19) e, novamente, diante dos estudos realizados por importantes instituições de saúde nacionais e internacionais, a vacina contra esta doença desperta, em terras brasileiras, desconfianças, temores e,discursos contrários à vacinação da população. É com este tema que se ocupa o tópico a seguir.

\section{NOS ALBORES DO SÉCULO XXI... UMA PANDEMIA, NEGACIONISMOS E... UMA NOVA REVOLTA DA VACINA?}

O reconhecimento de uma pandemia causada pela Covid-19, pela Organização Mundial da Saúde (OMS), ocorreu em coletiva de imprensa realizada no dia 11 de março de 2020, por Tedros Adhanom Ghebreyesus, Diretor-geral da OMS. Em virtude da doença, que ceifou centenas de milhares de vidas mundo a fora, computam-se, no Brasil, até o momento, 205.964 mortes, além de 8.256.536 casos de infecção ${ }^{14}$.

\footnotetext{
${ }^{13}$ Versão completa da referida edição pode ser consultada em:

http://memoria.bn.br/pdf/116300/per116300_1904_00111.pdf. Acesso em: 13 jan. 2021.

${ }^{14}$ Dados disponíveis em:

https://www.google.com/search?source=hp\&ei=OZcAYNSINdy65OUPo4yKkAI\&q=numeros+atualizados+covid
} 


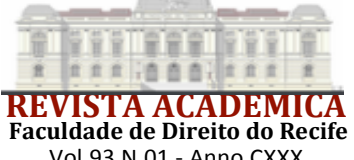

Vol.93 N.01 - Anno CXXX

A pandemia do coronavírus instituiu uma situação inédita, como refere Pérez Tapias (2020) "não apenas pela rápida cadeia de contágios da consequente doença de caráter gripal, mas também pelas medidas sanitárias decididas politicamente para buscar freá-la", somadas ainda as "custosas consequências econômicas e sociais a longo prazo e por todo o planeta." Neste contexto, prossegue o autor, a suposta "ordem econômica internacional", restou colocada "de cabeça para baixo por um microscópico vírus protagonista de outra face da globalização!" E, se "pensávamos que tínhamos tudo sob controle", a pandemia evidenciou que não há controle tecnológico nem econômico: "daí a tremenda cura de humildade que a pandemia desencadeada nos inflige".

Por seu ineditismo, muitas interpretações e possíveis explicações da reconhecida pandemia foram sendo produzidos, incluindo toda sorte de fatalismo, teorias da conspiração, discursos de descrédito e de pânico. Todos estes discursos tem circulado diariamente pelos principais meios de comunicação do Brasil e do mundo, sobretudo nas novas mídias sociais, escancarando, mais uma vez, a utilização de fake news como instrumento de desinformação.

$\mathrm{Na}$ atualidade, a questão das fakenews "extrapolou o nível técnico da credibilidade jornalística para recair, como tática de construção e desconstrução de imagens eleitorais, na dimensão política das ameaças internas e externas à democracia" (SACRAMENTO; PAIVA, 2020 , p. 83). Muitas dessas informações falaciosas passaram a estar vinculadas à pesquisa e produção da vacina contra o novo coronavírus, em um processo que se constitui na esteira do agravamento do descrédito na ciência e no conhecimento formal que tem sido fomentado no país nos últimos anos.

Esta situação mostra-se extremamente gravosa, uma vez que, conforme explicitam Tertuliano e Stein (2011), a vacina é uma intervenção preventiva reconhecida pelo impacto na redução da morbimortalidade de doenças imunopreveníveis. E a prática de vacinação em massa se fundamenta na característica de imunidade de grupo, em que indivíduos imunes vacinados protegem indiretamente os não vacinados, podendo gerar a eliminação da circulação do agente infeccioso no ambiente e, deste modo, gerar a proteção da coletividade e de indivíduos vulneráveis (LESSA, SCHRAMM, 2015).

As políticas públicas de vacinação foram institucionalizadas, no Brasil,através da criação do Programa Nacional de Imunizações (PNI), instituído pela Lei ${ }^{\circ} 6.259$, de 30 de outubro de 1975. Este programa regulou as ações de vigilância epidemiológica, vacinação e notificação compulsória de doenças no país, fornecendo ao Estado brasileiro um marco normativo de grande importância quanto à obrigatoriedade das vacinações. Uma vez que havia sido formulada antes da vigência da Constituição Federal de 1988 e do surgimento do Sistema Único de Saúde (SUS), a Lei $n^{0} 6.259 / 75$ prevê, no seu art. $3^{\circ}$, que compete ao Ministério da Saúde a elaboração do PNI, que definirá as vacinações, sua obrigatoriedade, e ainda, que "as vacinações obrigatórias serão praticadas de modo sistemático e gratuito pelos órgãos e entidades públicas, bem como pelas entidades privadas, subvencionadas pelos Governos Federal, Estaduais e Municipais, em todo o território nacional". (BRASIL, 1975).

Referida Lei foi regulamentada através do Decreto $n^{\circ} 78.231$ 4, de 12 de agosto de 1976, o qual forneceu maiores detalhes sobre o modo como a obrigatoriedade da vacinação seria implementada no Brasil.Conforme descrito no art. 27 do regulamento, "serão obrigatórias, em todo o território nacional, as vacinações como tais definidas pelo Ministério da Saúde, contra as doenças controláveis por essa técnica de prevenção, consideradas relevantes no quadro nosológico nacional". (BRASIL, 1976).

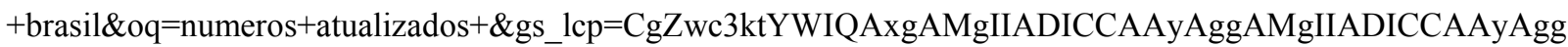
AMgIIADICCAAyAggAMgIIADoFCAAAQsM6CAguELEDEIMBOggIABCxAxCDAToLCAAQsQMQxwEQo wI6DggAELEDEIMBEMcBEK8BUJ8DWLoVYP0jaABwAHgAgAHcAYgBmxeSAQYwLjE5LjGYAQCgAQG qAQdnd3Mtd216\&sclient=psy-ab. Acesso em: 14 jan. 2021. 


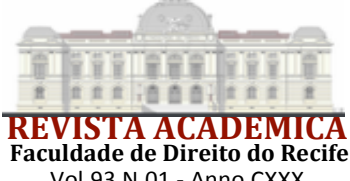

Vol.93 N.01 - Anno CXXX

De acordo com Silva Junior (2013), aimplementação do PNI proporcionou mais de 40 anos de êxitos, reconhecidos e respeitados na comunidade internacional, tornando-o um programa de Saúde Pública de referência para vários países. Para seu sucesso, afirma Sato (2018), contribuíram o aprimoramento do programa, o avanço da pesquisa, e desenvolvimento e produção de imunobiológicos no país somados ainda ao favorecimento da adesão oportunizado pelas campanhas e os dias nacionais de vacinação que expressavam a mobilização pública. Houve também a melhora da comunicação e mídia das ações de vacinação (TEMPORÃO, 2003).

Apesar desses e outros avanços, evidências epidemiológicas têm revelado tensões no âmbito da aceitabilidade da vacinação por alguns segmentos sociais, fenômeno que tem ganhado importância em várias partes do globo e se caracteriza pelo atraso vacinal ou pela recusa da vacina, independentemente de sua disponibilidade e do acesso aos serviços de saúde (SATO, 2020; SOUZA et. al, 2019).

Conforme apontam Brown et al (2018), apesar da evidência esmagadora sobre os benefícios gerais da imunização, a hesitação vacinal tem ganhado terreno considerável, revelando-se um sério motivo de preocupação, pois tem sido associada ao ressurgimento de doenças evitáveis por vacinas, como sarampo e poliomielite. Conforme aponta sua pesquisa, níveis mais baixos de confiança nas vacinas estavam associados a níveis mais altos de hesitação, ou seja, quanto menor a confiança nas vacinas, maior a hesitação, o que leva menos pessoas a aderirem à vacinação.

Segundo Souza et. al (2019, p. 41), este atraso ou recusa vacinal pode estar vinculado à atuação de grupos antivacinação, cujo movimento "foi inserido pela Organização Mundial de Saúde (OMS) em seu relatório, como um dos dez maiores riscos à saúde mundial”. A referida Organização considera a periculosidade deste movimento, na medida em que "ameaça retroceder o progresso obtido no combate a doenças imunopreveníveis, como por exemplo a poliomielite e o sarampo".Este movimento tem crescido nos últimos anos, mobilizando "pais e pessoas em geral, que não imunizam seus filhos e nem a si próprios, causando diminuição das coberturas vacinais, facilitando a porta de entrada para doenças ainda pouco conhecidas e pondo em risco a vida de outras pessoas."

Atrelado ao crescimento do movimento antivacina, vislumbra-se a circulação massiva de fake news por meio das redes digitais, que tem feito multiplicarem-se os discursos contra os métodos de imunização para doenças altamente contagiosas, cem anos após o evento devastador da Gripe Espanhola, que infectou mais de seiscentos milhões e vitimou entre vinte e quarenta milhões de pessoas em todo o mundo (SOUZA, 2008). Tais discursos compõem o conteúdo deposts, áudios e vídeos que se espalham por redes digitais e aplicativos de trocas de mensagens, reverberando argumentos que, supostamente, reivindicam a defesa da proteção do corpo contra todos os tipos de vírus, anunciam os riscos associados à vacinação - efeitos adversos, muitos propagados como fatais, benefícios maiores à indústria farmacêutica do que aos cidadãos, formas mais eficazes e naturais de proteção da saúde - e representam, em grande medida, o resultado da ação de pessoas integrantes de grupos e comunidades que compõe movimentos antivacina (SACRAMENTO; PAIVA, 2020).

Segundo Shimizu (2018, p. 87),

Os grupos antivacinas se fortaleceram e ganharam mais adeptos principalmente depois da publicação de um artigo fraudulento na revista britânica Lancet em 1998, pelo médico Andrew Wakefield que relacionava a síndrome de espectro do autismo com a vacina tríplice viral contra o sarampo, caxumba e rubéola. Esta relação foi descartada pela comunidade científica em novos estudos, mas o dano já havia sido feito; o boato de que a vacina tríplice viral causa autismo perdura até hoje e é um dos discursos que circulam nos grupos antivacinas. 


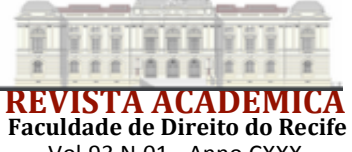

volude de Direito do Recife

Vol.93 N.01 - Anno CXXX

Neste sentido, estudo realizado pela Avaazem parceria com a Sociedade Brasileira de Imunizações $(\mathrm{SBIm})^{15}$ - analisou o papel que informações incorretas, difundidas por meio das redes sociais e de aplicativos de mensagens de celular, exercem no que se refere à redução das taxas de cobertura vacinal no país, as quais atingiram seus níveis mais baixos, após 16 anos, em 2017. De acordo com o estudo, "o período crítico começou em 2017 , quando $25 \%$ da população em risco de contrair febre amarela, a maioria crianças, não foi vacinada", sendo que dados mais recentes indicam "que apenas $88 \%$ da população-alvo foi vacinada contra sarampo em todo o país este ano (o percentual mínimo para a eliminação desta doença é 95\%), enquanto 100 municípios vacinaram menos de $50 \%$ da população-alvo contra a poliomielite." (AVAAZ, 2019, p. 4).

Na primeira fase do estudo, entre os dias 19 e 22 de setembro de 2019, o IBOPE Inteligência realizou uma pesquisa presencial e domiciliar entrevistando 2002 pessoas com 16 anos ou mais para avaliar "a percepção dos brasileiros sobre vacinas e como as fontes de informação utilizadas por eles estavam impactando as escolhas em relação à vacinação." (AVAAZ, 2019, p. 12). Sobre o tema, a pesquisa indicou que a mídia tradicional (televisão, rádio, jornais e sites de notícias da grande imprensa) se destaca como a fonte mais citada (68\%). Por seu turno, as redes sociais (Facebook, YouTube, Instagram e WhatsApp) ficaram em segundo lugar (48\%), sendo mencionados por quase metade da populaçãocomo fontes de informação sobre vacinas. Já as fontes que, tradicionalmente são as mais confiáveis e qualificadas para fornecer informações sobre o tema (Governo/Ministério da Saúde e profissionais de saúde) ocupam o $4^{\circ}$ e $5^{\circ}$ lugar, respectivamente, conforme aponta o gráfico a seguir:

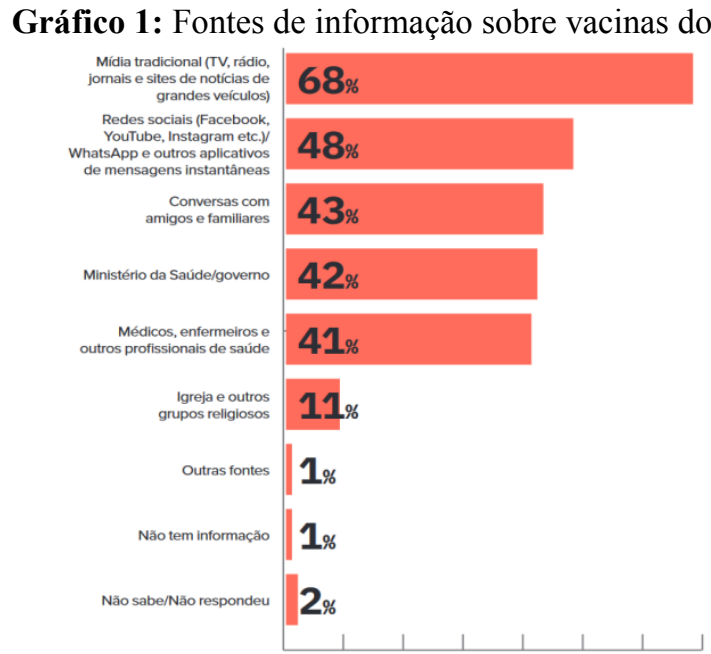

Fonte: AVAAZ, 2009, p. 23.

Neste contexto, apontam Brown et al (2018), algumas razões históricas para as quedas nas taxas de vacinação ainda desempenham um papel fundamental na hesitação vacinal, incluindo questões políticas, religiosas, e evidências tendenciosas, com os discursos girando em torno de alguns temas comuns, "como questões de segurança, resistência religiosa contra interferir no 'plano de Deus' ou da mãe natureza e resistência libertária contra mandatos".

Embora, como Brown et al (2018) reconheçam, o escopo dos episódios mais recentes de hesitação e recusa da vacina tenham novos modos de propagação, é possível estabelecer paralelos entre movimentos históricos, como o descrito no primeiro tópico deste artigo, e a atualidade. Este paralelo é demonstrado pelo quadroconstruído em pesquisa elaborada por

${ }^{15}$ Instituição membro da VaccineSafety Net (Rede de Segurança de Vacinas - VSN), uma rede global coordenada pela Organização Mundial da Saúde (OMS). 
Shimizu (2018), que retrata a repristinação, na contemporaneidade, por adeptos dos movimentos antivacina no Brasil, de argumentos utilizados à época da Revolta da Vacina. A coluna esquerda traz recortes extraídos do jornal "Correio da Manhã", em várias edições do ano de 1904 compiladas pela autora sobre a lei de obrigatoriedade da vacina e a coluna da direita apresenta recortes atuais extraídos de postagens e comentários de uma página antivacinação no Facebook ${ }^{16}$, a demonstrar que, em profundidade, pouco mudou o discurso antivacina entre a população brasileira no que tange aos seus fundamentos:

\begin{tabular}{|c|c|}
\hline Revolta da vacina (1904) & Movimento antivacina (2018) \\
\hline 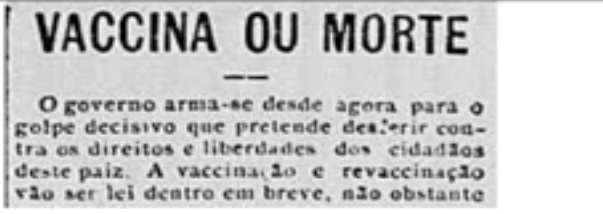 & \multirow{2}{*}{$\begin{array}{l}\text { Obrigar pais a envenenarem seus filhos com vacinas é } \\
\text { "legal" também, conforme vimos no post que o Senado } \\
\text { publicou ontem. } \\
\text { É "legal", mas nāo é justo. É inconstitucional e fere os } \\
\text { direitos humanos. Lutemos pelos nossos direitos! E } \\
\text { pelo direito dos nossos filhos de serem tutelados por } \\
\text { nós - os legítimos defensores de seus interesses - e năo } \\
\text { pelo Estado e seus burocratas. }\end{array}$} \\
\hline $\begin{array}{l}\text { O attentado planejado alveja o que de } \\
\text { mais sagrado contem o patrimunio do } \\
\text { cada cidadaso: pretende se esmagar a li- } \\
\text { berdade individual sob a forsa. bruta, }\end{array}$ & \\
\hline 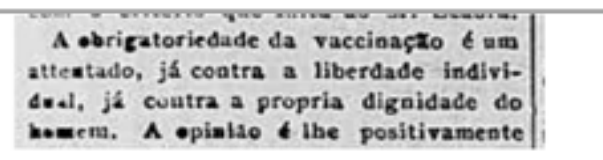 & $\begin{array}{l}\text { o nosso pais năo presta não temo direito de } \\
\text { opinar se queremos não essa droga de } \\
\text { vacina em nossas criancas ela mata de }\end{array}$ \\
\hline 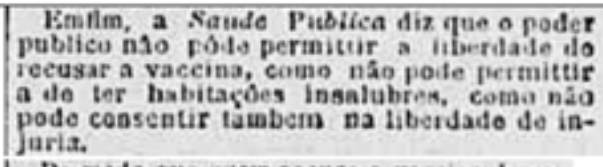 & \multirow[b]{2}{*}{$\begin{array}{l}\text { Senado. Tiro no pé. Quanto mais forçarem, } \\
\text { mais resistência haverá. E se quiserem uma } \\
\text { nova Revolta da Vacina basta continuarem } \\
\text { nesse caminho. }\end{array}$} \\
\hline 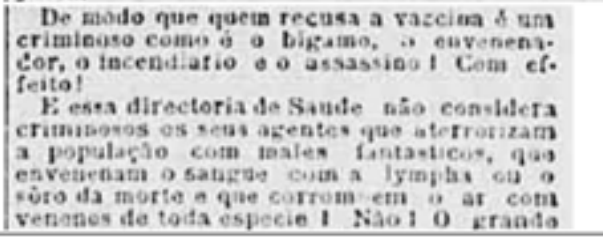 & \\
\hline 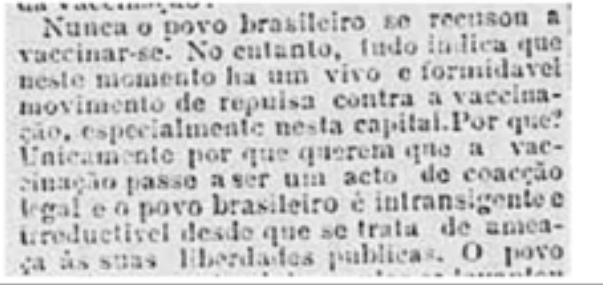 & $\begin{array}{l}\text { Ridículo vc não ter o poder de escolha...cada } \\
\text { um sabe o que é melhor pra aí é pros } \\
\text { filhos....que democracia é essa em que } \\
\text { vivemos????? }\end{array}$ \\
\hline
\end{tabular}

Quadro 1: Discursos antivacina no Brasil em dois tempos históricos Fonte: SHIMIZU, 2018, p. 93.

O que se pode observar, conforme apontam Teixeira e Santos (2020), é que em grande parte dos casos, as notícias produzidas com teor de falsidade desvalorizamas evidências científicasem direção à preservação da vida. Deste modo, aponto Shimizu (2018, p. 95), o movimento antivacinabrasileiro da atualidade "atua como um mecanismo no processo de produção discursiva, ao mesmo tempo em que materializa as condições de produção sob as quais ele é constituído", agindo semelhantemente à denominada "Liga contra a vacina obrigatória" à época da Revolta da Vacina, "mas também se inscreve na atualidade como a própria 'Revolta' através do ativismo virtual que reverbera nas práticas sociais e nos movimentos da sociedade". Portanto, "diferentemente do passado, o acontecimento de que se fala atualmente é o modo com que os sujeitos ressignificam toda uma memória discursiva da 'Revolta' pelo digital", fazendo

${ }^{16}$ Disponível em: <https://www.facebook.com/groups/1541114232797859/?ref=br_rs>. Acesso em: 13 jan. 2021. 


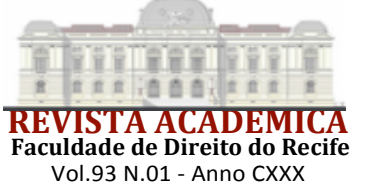

circular outros dizeres, movimentando outros sentidos para a vacina que "transbordam o virtual e se materializam em gestos concretos nas ruas, produzindo efeitos nos sujeitos, na sociedade e na cidade."

É neste contexto que deve ser analisado, no Brasil, o ataque por meio de fakenews dirigido à campanha de vacinação contra o novo coronavírus, que pode ser inferido das postagens abaixo reproduzidas, extraídas de redes sociais:

Figura 3: Fakenews - Vacina com nano-chip

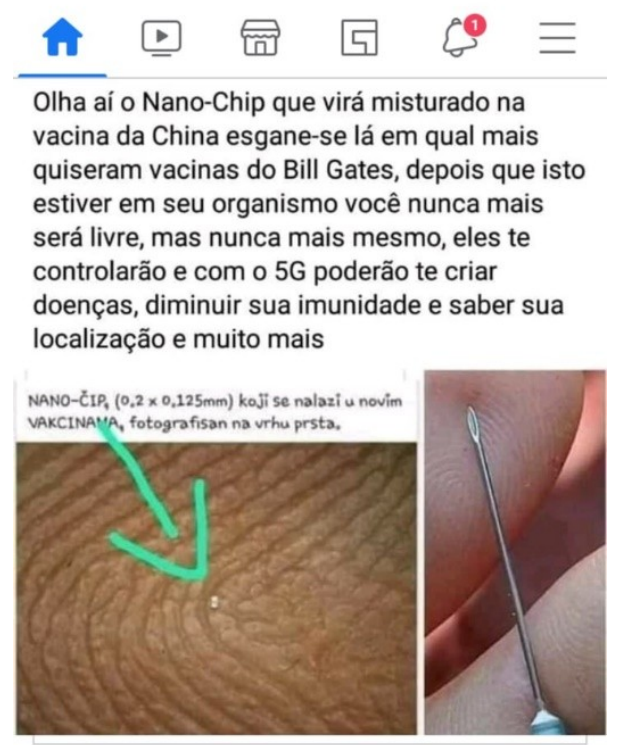

(1) 1

Fonte: FORATO, 2020.

Figuras 4:Fakenews - Discursos religiosos fundamentalistas
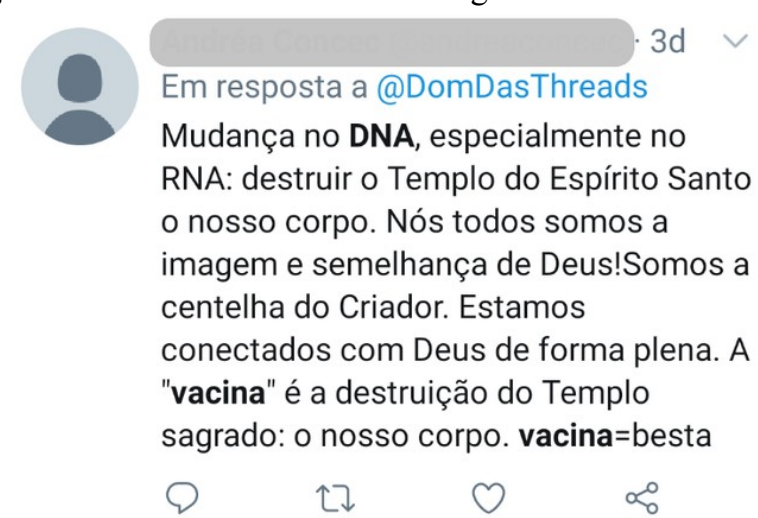

Fonte: FORATO, 2020. 
Figura 5:Fakenews - Vacina feita com células de fetos humanos como Bill Gates, quando se trata de uma vacinação contra o Coronavírus, dizendo que deveria ser "universal e para todos", mesmo que a vacina seja feita com células de fetos... instagram.com/p/ CEXw3nOJ3nU/...

$\begin{array}{llll}\uparrow \downarrow 1 & O & 1\end{array} \alpha_{0}^{\circ}$

Este contexto fez com que o Brasil vivenciasse a maior crise global humanitária, sanitária e econômica de nosso tempo, provocada pelo Coronavírus, paralelamente à outro grave problema, macroscópico: a omissão do Estado Brasileiro para adotar as medidas de controle da pandemia, inclusive no que diz respeito à vacinação (BARRETO, 2020). Brownet al (2018) revelam que posturas e ambientes políticos estão diretamente vinculados à hesitação vacinal, e quanto maior a instabilidade política, maior a desconfiança nas políticas vacinais e políticas de prevenção de um modo geral. Isto porque, segundo os autores, um grande impulsionador da relutância da vacina seria a questão da desconfiança - desconfiança no produto (incluindo informações sobre a vacina), no provedor e no formulador de políticas e na política circundante (governos). Os aurores citam como exemplo deste processo o fato de no Brasil, a recente instabilidade política e econômica que culminou no impeachment do governo em 2016, ter coincidido com um aumento em massa do Aedes aegypti- e das doenças transmitidas, nomeadamente dengue e zika.

Uma vez que a maior adesão à vacina está vinculada à estabilidade e confiança, inclusive políticas, a instrumentalização da desconfiança populacional - seja pela divulgação de fakenews, ou mesmo através de falas e discursos de autoridades políticas, religiosas, dentre outras - também pode ser ativada para gerar ou potencializar ambientes de instabilidade: um exemplo, segundo Brown et al (2018), seria o boicote da vacina contra a poliomielite no norte da Nigéria em 20032004, impulsionado por líderes com uma agenda além da vacina ou do programa de imunização, que capitalizaram os sentimentos antisistêmicos de populaçõespropensas a suspeita de programas governamentais. No Brasil, no entanto, durante o enfrentamento à pandemia do novo Coronavírus, verifica-se que é o próprio governo quem indica sinais de instrumentalização dos sentimentos de desconfiançada população, que podem repercutir em uma maior hesitação vacinal e aprofundando o fosso da desigualdade social que atinge o país.

Segundo Giovanella (2020), "esse é um governo que fez recrudescer a desigualdade social, já tão profunda em nosso país", de modo que "a pandemia desvelou a desigualdade brasileira. E a desigualdade mata: os dados já mostram maiores taxas de óbitos entre populações de menor renda e entre pessoas negras". A autora informa que o "inquérito sorológico nacional realizado pela Universidade Federal de Pelotas (UFPel) mostrou que a incidência nos 20\% mais pobres da população $(4,1 \%)$ é mais do que o dobro da incidência entre os $20 \%$ de maior renda $(1,8 \%)$.’'E infelizmente, segundo apontam Brown et al (2018), os resultados de sua pesquisa reverberam e aprofundam esta desigualdade: é justamente a população de faixa de renda mais baixa, as maiores vítimas das armadilhas das fakenews acerca da vacinação, revelando as menores taxas de aceitação da vacinação e potencialmente as maiores taxas de hesitação vacinal.

Como ressalta Ventura (2020), a pandemia do coronavírus nada tem de democrática, na medida em que, em realidades sociais como a brasileira, a doença "vai ser sempre sentida de forma diferente a depender do número de pessoas e essa doença é mais letal entre pessoas vulneráveis." Nesse sentido, "precisamos considerar quem é que tem direito aos bens da vida como água potável, saneamento básico, moradia decente, educação, trabalho", uma vez que 


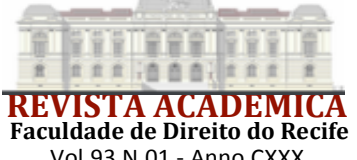

Vol.93 N.01 - Anno CXXX

"esses determinantes sociais chamam a atenção para o fato de que a saúde é determinada por muitos fatores pelos quais vamos ter grupos mais ou menos suscetíveis." Isso não significa "que o rico não adoeça e não morra, mas até morrer tudo é diferente. O tipo de doença, a incidência da doença, como vivi essa doença, como a doença e a minha morte impactam na minha família. A única igualdade é a morte em si e isso não queremos, o resto é tudo desigual."

Analisando-se o contexto dos movimentos antivacina nos dois momentos históricos analisados no presente estudo, evidencia-se que o Brasil desde sempre vive uma verdadeira pandemia da desinformação que, aliada ao modo truculento com que historicamente articula políticas públicas voltadas às camadas subalternizadas, geram pânico, alarma injustificado e um clima de suspeição generalizada que, na contemporaneidade, tem sido impulsionado ainda mais em face da sociedade informacional em rede, em um cenário de alta polarização política que acentua, ainda mais, as questões apontadas. Nesse sentido, é urgente a implantação de medidas compensatórias como campanhas de conscientização e sensibilização da população para os benefícios da imunização, o acesso universal à vacinação, a construção de redes socioeconômicas para o reequilíbrio da economia, o investimento em políticas de atenção terciária para recuperação das sequelas dos pacientes acometidos pelo novo coronavírus.

\section{CONSIDERAÇÕES FINAIS}

A partir da análise empreendida no presente estudo foi possível vislumbrar que o movimento higienista esteve amplamente presente na vida dos brasileiros no início do século XX e que lidou com problemas queainda hoje permeiam o cotidiano das populações como, por exemplo, a discriminação racial, a pobreza, o oportunismo político, a discriminação e o acesso dificultoso aos serviços de saúde.

Nota-se que as políticas de vacinação e a saúde pública estiveram, no Brasil, a serviço de um projeto social que buscava o controle, a eliminação e a erradicação das doenças imunopreveníveis, no escopo de construção deuma sociedade ideal, moderna, civilizada e democrática - o que perpassava, reflexamente, por um viés racista e seletivo de enfrentamento das questões relacionadas à associação conceitual equivocada entre pobreza e doença.

$\mathrm{Na}$ contemporaneidade evidencia-se que o conceito de hesitação vacinal tem sido usado, tanto nos meios acadêmicos quanto em saúde pública, para alertar sobre a preocupação com a possibilidade de ressurgimento de doenças infecciosas em estágio de controle, além de discussões éticas e comportamentais. O maior desafio dos profissionais da saúde e cientistas, neste momento, é o enfrentamento dos discursos negacionistas para a garantia da vida e a melhoria da qualidade de vida da população mais vulnerável às doenças.

Os medos e inseguranças que fomentaram a denominada Revolta da Vacina, no Rio de Janeiro, em 1904, ainda estão presentes em boa parcela da população que, vulnerável às fakenews e à polarização política, recusam-se, em pleno Século XXI, a acreditar na ciência e naqueles que se dedicam ao estudo da imunização. Esse cenário ficou ainda mais evidente no contexto da pandemia da Covid-19, que realçou as assimetrias sociais e repristinou, de certa medida, a história já vivenciada pela população brasileira na incipiente República. Dois tempos de história, uma mesma história: a desinformação na base da opressão.

\section{REFERÊNCIAS}

AYUB, João Paulo. Introdução à analítica do poder de Michel Foucault. São Paulo: Intermeios, 2014. 
BARRETO, Mauricio L.Ciência, política, história e os intrigantes e persistentes mistérios das pandemias. Ciência \& Saúde Coletiva, v. 25, p. 4094-4095, 2020. Disponível em: https://doi.org/10.1590/1413-812320202510.2.31302020. Acesso em: 13 jan. 2021.

BAZZICALUPO, Laura. Biopolítica:um mapa conceitual. São Leopoldo: UNISINOS, 2017.

BENJAMIN, Walter. Sobre o conceito de história. Trad. João Barrento. Belo Horizonte: Autêntica Editora, 2012.

BRASIL. Lei n 1.261, de 31 de outubro de 1904. Torna obrigatorias, em toda a Republica, a vaccinação e a revaccinação contra a variola. Disponível em:

https://www2.camara.leg.br/legin/fed/lei/1900-1909/lei-1261-31-outubro-1904-584180-

publicacaooriginal-106938-pl.html. Acesso em: 13 jan. 2021.

BRASIL. Lei no 6.259, de 30 de outubro de 1975. Dispõe sobre a organização das ações de vigilância epidemiológica, sobre o programa nacional de imunizações, estabelece normas relativas à notificação compulsória de doenças, e dá outras providências. Disponível em: https://www.planalto.gov.br/ccivil_03/leis/16259.htm. Acesso em: 13 jan. 2021.

BRASIL. Decreto no 78.231, de 12 de agosto de 1976. Regulamenta a Lei no 6.259, de 30 de outubro de 1975, que dispõe sobre a organização das ações de vigilância epidemiológica, sobre o programa nacional de imunizações, estabelece normas relativas à notificação compulsória de doenças, e dá outras providências. Disponível em: https://https://www.planalto.gov.br/ccivil_03/decreto/1970-1979/d78231.htm. Acesso em: 13 jan. 2021.

BROWN, Amy Louise et al. Confiança nas vacinas e hesitação em vacinar no Brasil. Cadernos de Saúde Pública, v.34, n.9, 2018. Disponível em: https://www.scielo.br/scielo.php?script=sci_arttext\&pid=S0102-

311X2018000905014\&lng=en\&nrm=iso\&tlng=en. Acesso em: 21 fev. 2021.

CARVALHO, José Murilo de. Os bestializados:o Rio de Janeiro e a República que não foi. São Paulo: Companhia das Letras, 1987.

CHALHOUB, Sidney. Cidade febril:cortiços e epidemias na Corte Imperial. São Paulo: Companhia das Letras, 1996.

CHALHOUB, Sidney. A força da escravidão: ilegalidade e costume no Brasil oitocentista. São Paulo: Companhia das Letras, 2012.

COELHO, Luiz. Cabeça de porco. Revista Landa, v. 3, n. 1, p. 174-194, 2014. Disponível em: http://www.revistalanda.ufsc.br/PDFs/vol3n1/10.\%20CHAMADA.\%20Luiz\%20Coelho\%20\%20Cabe\%C3\%A7a\%20de\%20porco.pdf. Acesso em: 01 ago. 2017.

COSTA, Angela Marques da; SCHWARCZ, Lilia Moritz. 1890-1914: no tempo das certezas. São Paulo: Companhia das Letras, 2000. 


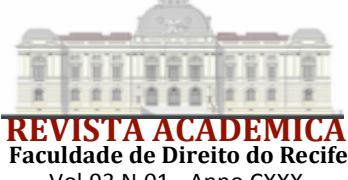

Faculdade de Direito do Recife

Vol.93 N.01 - Anno CXXX

FORATO, Fidel. As maiores fakenews sobre vacinas contra COVID-19. Canal Tech, 21 set. 2020. Disponível em: https://canaltech.com.br/saude/fake-news-vacina-covid-19-169052/. Acesso: 14 jan. 2021.

FOUCAULT, Michel. O nascimento da medicina social. In. FOUCAULT, Michel. Microfísica do poder.18. ed. Rio de Janeiro: Edições Graal, 2003. p. 79-98.

FOUCAULT, Michel. Em defesa da sociedade:curso no Collège de France (1975-1976). 2. ed. São Paulo: WMF Martins Fontes, 2010.

GIOVANELLA, Ligia et al. Negacionismo, desdém e mortes: notas sobre a atuação criminosa do governo federal brasileiro no enfrentamento da Covid-19. Saúde em Debate, v. 44, n. 126 p. 895-901. Disponível em: https://doi.org/10.1590/0103-1104202012623. Acesso em: 13 jan. 2021.

LE GOFF, Jacques. História e memória.Trad. Bernardo Leitão. 4. ed. Campinas: Unicamp, 1996.

LESSA, Sérgio de Castro; SCHRAMM, Fermin Roland. Proteção individual versus proteção coletiva: análise bioética do programa nacional de vacinação infantil em massa. Ciência \& Saúde Coletiva, 2015, v. 20, n. 1, p. 115-124. Disponível em: https://doi.org/10.1590/141381232014201.14882013. Acesso em: 13 jan. 2021.

PÉREZ TAPIAS, José Antonio. Entre o risco e o medo, a biopolítica em alta. Instituto Humanitas UNISINOS, 17 mar.2020. Disponível em: http://www.ihu.unisinos.br/78noticias/597147-entre-o-risco-e-o-medo-a-biopolitica-em-alta. Acesso em: 19 mar. 2020.

PREFEITURA DA CIDADE DO RIO DE JANEIRO. Memória da destruição:Rio - uma história que se perdeu (1889-1965). Rio de Janeiro: Secretaria das Culturas, Arquivo da Cidade, 2002.

SACRAMENTO, Igor; PAIVA, Raquel. Fakenews, WhatsApp e a vacinação contra febre amarela no Brasil. Revista Matrizes,v.14, n. 1, 2020. Disponível em:

https://www.revistas.usp.br/matrizes/article/view/160081. Acesso em: 21 fev. 2021.

SANTOS, André Leonardo Copetti; WERMUTH, Maiquel Ângelo Dezordi. Michel Foucault e a arquealogia/genealogia do poder: da sociedade disciplinar à biopolítica. Quaestio Iuris.Rio de Janeiro, v. 09, n. 01, p. 405-424, 2016.

SATO, Ana Paula Sayuri. Pandemia e coberturas vacinais: desafios para o retorno às escolas. Rev. Saúde Pública, São Paulo, v. 54, n. 115, 2020.Disponível em: https://doi.org/10.11606/s1518-8787.2020054003142.Acesso em: 13 jan. 2021.

SCHWARCZ, Lilia Moritz. O espetáculo das raças: cientistas, instituições e questão racial no Brasil - 1870-1930. São Paulo: Companhia das Letras, 2017.

SCLIAR, Moacyr. Políticas de saúde pública no Brasil: uma visão histórica. In. SCLIAR, Moacyr; PAMPLONA, Marco A.; RIOS, Miguel Angelo Thompson; SOUZA, Maria Helena Soares de. Saúde pública:histórias, políticas e revolta. São Paulo: Scipione, 2002. p. 45-64. 


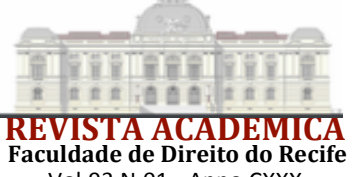

Faculdade de Direito do Recife

Vol.93 N.01 - Anno CXXX

SEVCENKO, Nicolau. A Revolta da Vacina:mentes insanas em corpos rebeldes. São Paulo: UNESP, 2018.

SHIMIZU, NatiellyRallo. Movimento antivacina: a memória funcionando no/pelo (per)curso dos sentidos e dos sujeitos na sociedade e-urbana. Revista do Edicc, v. 5, n. 1, p. 87-97, out. 2018. Disponível em: http://revistas.iel.unicamp.br/index.php/edicc/article/viewFile/5963/7310. Acesso em: 14 jan. 2021.

SILVA JUNIOR, Jarbas Barbosa da. 40 anos do Programa Nacional de Imunizações: uma conquista da Saúde Pública brasileira. Epidemiol. Serv. Saúde, Brasília, v. 22, n. 1, p. 7-8, mar., 2013. Disponível em:http://dx.doi.org/10.5123/S1679-4974201300010000.Acesso em: 13 jan. 2021.

SOUZA, Christiane Maria Cruz de. A epidemia de gripe espanhola: um desafio à medicina baiana. Hist. cienc. saude-Manguinhos, Rio de Janeiro, v. 15, n. 4, p. 945-972, dez. 2008. Disponível em:http://dx.doi.org/10.1590/S0104-59702008000400004.Acesso em: 13 jan. 2021.

SOUSA,Júlia Gomes; BARBOSA, Hellen Cavalcanti; SILVA, Magda Oliveira da; CAMPOS, José Rafael Eduardo; LUZ, Dayse Christina Rodrigues Pereira. Movimento antivacinação: uma ameaça à humanidade. Rev. e-ciência, v. 7, n. 2, p. 41-42, 2019. Disponível em:http://dx.doi.org/10.19095/rec.v7i2.885. Acesso em: 13 jan. 2021.

TEIXEIRA, Adriana;SANTOS, Rogério da Costa. FakeNews colocama vida em risco: a polêmica da campanha de vacinação contra a febre amarela no Brasil. Revista Eletrônica de Comunicação, v. 14, p. 72-89, 2020. Disponível em:https://doi.org/10.29397/reciis.v14i1.1979. Acesso em: 13 jan. 2021.

TEMPORÃO, José Gomes. O Programa Nacional de Imunizações (PNI): origens e desenvolvimento. Hist. cienc. saúde-Manguinhos, Rio de Janeiro, v. 10, p. 601-617, 2003. Disponível em:https://doi.org/10.1590/S0104-59702003000500008. Acesso em: 13 jan. 2021.

TERTULIANO, Gisele Cristina; STEIN, Airton Tetelbom. Atraso vacinal e seus determinantes: um estudo em localidade atendida pela Estratégia Saúde da Família. Ciênc. saúde coletiva, Rio de Janeiro, v. 16, n. 2, p. 523-530, Fev. 2011. Disponível em:https://doi.org/10.1590/S141381232011000200015.Acesso em: 13 jan. 2021.

TURINI, Leide Alvarenga. A crítica da história linear e da ideia de progresso: um diálogo com Walter Benjamin e Edward Thompson. Educação e Filosofia, v. 18, n. 35-36, p. 93-125, jan./dez. 2004.

VAZ, Lilian Fessler. Dos cortiços às favelas e aos edifícios de apartamentos: a modernização da moradia no Rio de Janeiro. Análise Social, v. 29, n. 127, 1994, p. 581-597. Disponível em: http://analisesocial.ics.ul.pt/documentos/1223377187I6iYL2uw3Xe43QN7.pdf. Acesso em: 12 jan. 2021.

VENTURA, Deisy de Freitas Lima. "Temos que ir pelo caminho de grande investimento público para a proteção das pessoas". O Povo online, 18 mar. 2020. Disponível em:

https://www.opovo.com.br/coronavirus/2020/03/18/temos-que-ir-pelo-caminho-de-grandeinvestimento-publico-para-a-protecao-das-pessoas.html. Acesso em: 14jan. 2021. 
WERMUTH, Maiquel Ângelo Dezordi. Medo e direito penal: reflexos da expansão punitiva na realidade brasileira. Porto Alegre: Livraria do Advogado, 2011. 